\title{
Biomass production of different grass species available at irrigated lowland of Dassench Woreda in South Western Ethiopia
}

\author{
D Hidosa $^{1 *}$, W Hitiso ${ }^{2}$ and M Guyo ${ }^{3}$
}

Affiliation: ${ }^{1}$ Southern Agricultural Research Institute, Jinka Agricultural Research Center, P.O. Box. 96; ${ }^{2}$ Southern Pastoral Bureau, RPLRP Project, Dassench Branch Coordinator, Dassench , Ethiopia; ${ }^{3}$ Maddawalabu University, Department of Animal and Range Science, P. Box.247, Bale-Robe, Ethiopia

\begin{abstract}
On farm adaptability test of different grass species was conducted on pastoral area of Keelewe peasant association in Dassench Woreda of South Omo Zone in 2016 under irrigated condition with the objective to identify high biomass yielding grass species. The field experiment was laid out in a Randomized Complete Block Design with four replicates per tested species. The tested grass species were Chloris gayana, Cenchrus ciliaris and Panicum colaratum. The result indicated that there was a significant difference $(p>0.05)$ among the tested grass species. Panicum colaratum yields the highest $(18.08 \mathrm{t} / \mathrm{ha})$ than the Chloris gayana (15.21 t/ha) whereas, Cenchrus ciliaris had yielded the lowest dry matter yield (11.20t/ha) than Chloris gayana and Panicum colaratum. The Panicum colaratum was one with maximum dry matter yield being recommended for irrigated conditions in the study area. However, further testing is required on feeding value, dry matter yield under different fertilizer dose, stem height, leaf to stem ratio, irrigation requirements and chemical composition of tested grass species.
\end{abstract}

Key words: dry matter yield, Chloris gayana, Cenchrus ciliaris and Panicum coloratum

Bangladesh Animal Husbandry Association. All rights reserved.

Bang. J. Anim. Sci. 2017. 46 (3): 188-191

\section{Introduction}

Duguma et al. (2012) and Tolera (2007) stated that low quality and quantity of livestock feed is one of impediments for low productivity of livestock in Ethiopia. Similarly, in pastoral area in which this study was made livestock nutrition is entirely depend on feed from natural pasture (Admasu et al., 2010) which is characterized by high structural cell wall constituents, low crude protein and metabolisable energy. This has been resulted in a slow growth rate, loss of body condition and increased susceptibility to diseases and parasites. On the other hand the research facts that reported by Hunegnaw and Brehan (2016) and Mekonnen et al. (2016) from the Ethiopia also demonstrated that feed intake, digestibility and growth performance of livestock could be improved when the livestock supplemented with quality forages to poor quality roughages. Among the potential grass forage species Cenchrus ciliaris is a one of pasture grass in the tropics has been yielded up to 24 t/ha DM under good management (Ecocrop, 2010; Osman et al., 2008). Furthermore, Chloris gayana is also one of grass family which identified as drought resistant and highly productive with average DM yield which ranged from 10-16 t DM/ha (Hidosa, 2015; Ecocrop, 2014).
However, in the lowland pastoral areas, recurrent drought and climatic variability limit availability and use of feed resources (Assefa et al., 2013). Therefore, introduction of drought tolerant exotic grass species which have a significant role in improving feed availability in dry areas. Availability of irrigation in the lowland areas of South Omo Zone presents an opportunity to mitigate production risk from drought. However, the dry matter production potential of these grasses has not been tested in to irrigated lowland. In this context, this study was aimed to identify grass species for their dry matter production potential in irrigated conditions of pastoral area.

\section{Materials and Methods}

\section{Deception of study area}

The study was conducted in pastoral area of South Omo Zone in South Western Ethiopia which is located astronomically by $50^{\circ} 14^{\prime} \mathrm{N}$ latitude, $36^{\circ} .44^{\prime} \mathrm{E}$ longitude with altitude ranges from 350 $900 \mathrm{~m}$ above sea level (SRFED, 2007). The temperature of the study area have been ranged between $25-40^{\circ} \mathrm{C}$ and whereas, the rainfall is has ranged from 350-600 with bimodal and erratic rainfall distribution patterns. The soils are 
Hidosa et al. (2017) Bang. J. Anim. Sci. 46 (3):188-191

shallow, coarse textured with moderate to high fertility status as dominating by silt alluvial soil type which is suitable for irrigation from the Omo River (SRFED, 2007).

\section{Selection of trial participants}

The Keelewe kebele was identified from the Dassench pastoral communities for this study with aid of both experts and developmental agents. The three energetic trial pastoralists' from the pastoral communities were selected based on their experience in irrigation and willingness in donation of trial plots without restrain.

\section{Experimental design and treatment}

The Chloris gayana, Cenchrus ciliaris and Panicum colaratum were used in this study. Each grass species was planted in area $3 \mathrm{~cm} \times 4 \mathrm{~cm}=$ $12 \mathrm{~cm}^{2}$ and arranged in Completely Randomized Block Design with four times replicated per species. The fully irrigation was applied equally in all the plots during the critical stages of grass species growth to ensure the minimum amount of water requirement for optimal forage yield.

Experimental site management and data collection

The planted grass species were managed by hoeing and weeding and all the trial plots had been continually monitored. The biomass data such as fresh biomass and dry matter yield was collected from the each grass species after three month planting when grass species at $50 \%$ heading stages. Four samples per species randomly harvested from the area of $50 \mathrm{~cm} \times 50$ $\mathrm{cm}=2500 \mathrm{~cm}^{2}$ by using sickle and then cut it in to small pieces and pooled over. The pooled samples were allowed oven dried at $105^{\circ} \mathrm{C}$ for $24 \mathrm{hrs}$ at Feed and Nutrition Laboratory which located at Jinka Agricultural Research Center. The total dry matter yield (t/ha) will be calculated by (total fresh/ha*\%DM)/100 and whereas \%DM = ODW/ (SFW*100).

\section{Data analysis}

The yield such as fresh and dry matter were subjected to Analysis of variances (ANOVA) and followed by GLM procedure of SAS (SAS, 2009). Effect of tested species was considered significantly if $(P \leq 0.01)$. The least means squares were separated by using Duncan's least significant difference (LSD) test by using model $Y_{i j}=A+B_{i}+t_{j}+e_{i j}$; where: $Y_{i j}=$ biomass yield recored, $A=$ General mean, $B i=$ block effects, $t j$ $=$ treatment effects and eij = Random error

\section{Results and Discussion}

\section{Fresh biomass yield}

The fresh biomass yield of grass species tested in irrigated lowland of Dassench Woreda was summarized in Table1. The fresh biomass yield recorded from this study revealed that Pancium coloratum had produced highest $(P<0.05)$ fresh biomass than Chloris gayana and Cenchru ciliaris. However, Cenchru ciliaris was produced relatively the lowest fresh biomass yield than Pancium coloratum and Chloris gayana. The fresh biomass yield ( $\mathrm{t} / \mathrm{ha}$ ) obtained from the current study for Pancium coloratum and Cenchru sciliaris is higher than previously reported values (40.8t/ha) and (33t/ha) by Hidosa (2015) respectively in rain fed condition at Jinka Agricultural Research Center on station trial. The higher, fresh biomass yield from this study from the Hidosa (2015) reported values might be due to effect of agro ecologies and irrigation, Soil fertility and management differences.

Table1. The fresh biomass yield tons / ha of grass species affected by irrigation in Dassench Woreda in 2016

\begin{tabular}{lllllllll}
\hline \multicolumn{7}{c}{ Yield parameters } \\
\hline $\begin{array}{l}\text { Tested grass } \\
\text { species }\end{array}$ & FBY( g/plot) & FBY t/ha & CV & LSD & F-value & $\begin{array}{l}\text { P- } \\
\text { value }\end{array}$ & SEM \\
\hline Chloris gayana & $1339^{\mathrm{b}}$ & 53.56 & 18.00 & 215.54 & 4.52 & 0.065 & $* *$ \\
Cenchrus ciliaris & $998^{\mathrm{a}}$ & 39.92 & 18.00 & 215.54 & 4.52 & 0.065 & $* *$ \\
Panicum colaratum & $1587^{\mathrm{c}}$ & 63.48 & 18.00 & 215.54 & 4.52 & 0.065 & $* *$ \\
\hline
\end{tabular}

Mean values in a column having different superscripts differ significantly each other; FMY = Fresh biomass yield $; \quad g=$ gram; $C V=$ Coefficient of variance; $L S D=$ Least significance difference; SEM = Standard error of mean; $* *=(\mathrm{P}<0.01)$; ha , Hactre. 
Table2. The dry matter yield t/ha of grass species affected by irrigation in Dassench Woreda in 2016

\begin{tabular}{lccccccc}
\hline \multicolumn{7}{c}{ Yield parameters measured } \\
$\begin{array}{l}\text { Tested legume } \\
\text { species }\end{array}$ & DM( g/plot) & DM/ha & CV & LSD & F-value & P- value & SEM \\
Chloris gayana & $380.20^{\mathrm{A}}$ & 15.21 & 5.20 & 65.04 & 1.74 & 0.254 & $*$ \\
Cenchrus ciliaris & $279.88^{\mathrm{B}}$ & 11.20 & 5.20 & 65.04 & 1.74 & 0.254 & $*$ \\
Panicum colaratum & $451.98^{\mathrm{C}}$ & 18.08 & 5.20 & 65.04 & 1.74 & 0.254 & $*$ \\
\hline
\end{tabular}

Mean values in a row having different superscripts differ significantly each other; DMY = Dry matter yield; $\mathrm{g}=$ gram; $\mathrm{CV}=$ Coefficient of variance; LSD = Least significance difference; SEM = Standard error of mean; $*=(\mathrm{P}<0.05) ;$ ha $=$ hectare .

Adane (2003) reported that the biomass yield production potential of forage species differed each other due to difference in cultivars, agro ecological effect and management practices which is corresponds to the current study. However, the fresh biomass yield of Chloris gayana obtained from the current study is in line with the fresh biomass yield reported by Tewdros and Messert (2013) from the Southern Ethiopia which had been ranging from 31.9-98.0 t/ha.

\section{Dry matter yield}

Pertaining to dry matter production potential of grass species recorded from this study was summarized in Table2. The result obtained on dry matter ( $t / h a)$ in fully irrigated condition from this study indicated that similar trends as fresh biomass yield among the three grass species. The significantly highest $(P<0.05)$ dry matter yield obtained from Panicum coloratum than Chloris gayana and Cenchrus ciliaris. However, significantly the lowest dry matter yield obtained from Cenchrus ciliaris than Panicum coloratum and Chloris gayana. Dry matter is important parameters in order to evaluate forage species for livestock production. Generally, the dry matter yields for the tested grass species show doubled increment than reported value by Hidosa(2015) from On-station research at Jinka Agricultural Research Center. However, the dry matter yield recorded for Chloris gayana from this study is corresponds to what Tessema (2008) reported value $f$ of $14 \mathrm{t} / \mathrm{ha}$ in rain fed conditions from the Ethiopia. Pertaining to dry matter value recorded from this study for Panicum colorutum is higher than values reported by Diriba (2000) which ranging from $9.48-15.39 \mathrm{t} \mathrm{ha}^{-1}$ in rain fed condition. Furthermore, the dry matter yield obtained in the current study for the Cenchrus ciliaris is higher than value (6.68 t/ha) reported by Hidosa (2015). Generally, result had obtained from this study for three grass species indicated that there is relatively two fold increase in dry matter yield in irrigated condition than rain fed condition even though Ayana and Oba (2010) reported comparable forage dry matter values which ranged between 10-16 t/ha under rain fed condition from the Southern Ethiopia for Cenchrus ciliaris and Chloris gayana.

\section{Conclusion and Recommendation}

The current study had shown that Panicum coloratum produced higher fresh and dry matter yield than Chloris gayana and Cenchru ciliaris under fully irrigated condition when compared to yield obtained from rain fed conditions. Based on the current result it could be concluded that better improvement was observed in fresh and dry matter yield of grass species in irrigated condition than non-irrigated condition especially in lowland areas of South Omo Zone which is characterized by high coefficient of variability in rainfall distribution patterns. However, further testing is required to put the recommendation on a strong basis since the current study data is from one cropping season. Moreover, the tested grass species were not evaluated as to their disease and pest resistance, seed production potential, nutritive and feeding values under different fertilizer rate and irrigation requirements.

\section{Acknowledgment}

We have great appreciation and thanks to Pastoral, Agro-Pastoral and Emerging Region Capacity Building Directorate for financial support and pastoralists for their actively participation in experimental activity and resource provisions. Finally, we greatly acknowledged peasant association Administrators and Development Agents and Jinka Agricultural Research Center for 
their support by generating ideas, support to the research activities and mobilizing community.

\section{References}

Admasu T, E Abule Erbo and Z Tessema (2010). Livestock-rangeland management practices and community perceptions towards rangeland degradation in South Omo zone of Southern Ethiopia. Livestock Research for Rural Development 22:5-5.

Ayana and Oba (2010). Effect of grazing pressure, age of enclosure and seasonality on bush cover dynamics vegetation composition in southern Ethiopia. Journal of Arid Environment 74:111-120.

Assefa D, A Nurfeta and S Banerjee (2013). Assessment of feed resource availability and livestock production constraints in selected Kebeles of Adami Tullu Jiddo Kombolcha District, Ethiopia, Africa Journal of Agricultural Research 8(29):4067-4074.

Diriba G (2000). Productivity and nutritional quality of Panicum coloratum under varying stages of harvest, different levels of nitrogen fertilizer and in combination with Stylosanthes guianensis during establishment year. An Msc thesis presented to the School of Graduate of Alemaya University. $80 \mathrm{p}$

Duguma B., A Tegegne and BP Hegde (2012). Smallholder livestock production system in Dandi district, Oromia Regional State, Central Ethiopia. Global Veterinaria 8(5):472-479.

Ecocrop (2010). Ecocrop data base FAO; Rome, Italy.

Ecocrop (2014). Ecocrop data base FAO; Rome, Italy.

Denbela H (2015). Adaptation and evaluation of Cenchrus ciliaris, Chloris gayana and Panicum coloratum grass species on station of Jinka Agricultural Research Center, Jinka, Ethiopia. International Journal of Agriculture and Biosciences 4(6): 236- 239.

Hunegnaw A and T Berhan (2016). Effects of supplementation with pigeon pea (Cajanus cajun), cowpea (Vigna unguiculata) and lablab (Lablab purpureus) on feed intake, body weight gain and carcass characteristics in Wollo sheep fed grass hay. International Journal of Advanced Research on Biological Sciences 3(2):280-295. 